\title{
Analisis Kemampuan Pemecahan Masalah Matematis Ditinjau dari Gaya Kognitif Siswa pada Materi Pythagoras
}

\author{
Dwi Rohmani $^{1}$, Rosmaiyadi ${ }^{2}$, Nurul Husna ${ }^{3}$ \\ STKIP Singkawang, Singkawang, Indonesia \\ wii.rohma@gmail.com ${ }^{1, *)}$, rosmaiyadialong@gmail.com ${ }^{2}$, nuna_husna@ymail.com \\ ${ }^{*}$ Corresponding author
}

Kata kunci :

Kemampuan Pemecahan Masalah Matematis; Gaya Kognitif; Field Dependent; Field Independent; Pythagoras

\begin{abstract}
ABSTRAK
Tujuan penelitian ini adalah untuk mendeskripsikan kemampuan pemecahan masalah siswa dengan gaya kognitif field dependent, field independent, dan faktor penyebab pada materi pythagoras. Jenis penelitian yang digunakan adalah penelitian deskriptif kualitatif. Teknik pengumpulan data menggunakan instrumen berupa GEFT dan tes uraian yang telah diuji menggunakan validasi isi, validasi konstruk, reliabilitas, daya pembeda, dan tingkat kesukaran. Teknik analisis data yang digunakan adalah reduksi data berupa penskoran, penyajian data berupa pendeskripsian dan wawancara, serta menarik kesimpulan. Hasil Penelitian menunjukan bahwa (1) kemampuan pemecahan masalah siswa dengan gaya kognitif field dependent kelompok tinggi berkategori baik, siswa dengan gaya kognitif field dependent kelompok sedang dan kelompok rendah berkategori kurang baik pada tahap-tahap indikator kemampuan pemecahan masalah, sedangkan pada kemampuan pemecahan masalah siswa dengan gaya kognitif field independent tidak ditemukan hasil penelitian dikarenakan tidak adanya siswa dengan gaya kognitif field independent di kelas tersebut; (2) faktor internal siswa meliputi ketidakmampuan menemukan konsep, strategi yang tidak tepat, tidak mampu melakukan proses perhitungan dan menyelesaikan masalah, tidak memahami materi dengan baik, kurang paham terhadap konsep pythagoras, malas, serta tidak teliti, sedangkan faktor eksternal meliputi, alokasi waktu, kondisi kelas yang ribut, tidak sungguh-sungguh, bermainmain, dan mengobrol, sehingga hasil yang diperoleh kurang maksimal.
\end{abstract}

\section{PENDAHULUAN}

Matematika merupakan disiplin ilmu yang mempunyai sifat khas. Kekhasan itu berkenaan dengan ideide atau konsep-konsep abstrak yang tersusun secara hirarkis. Mata pelajaran matematika perlu diberikan kepada semua peserta didik mulai dari sekolah dasar, untuk membekali peserta didik dengan kemampuan berpikir logis, analitis, sistematis, kritis, inovatif dan kreatif, serta kemampuan bekerjasama (Rosmaiyadi, 2017). Matematika di sekolah dari jenjang pendidikan dasar hingga kelas XII memelukan standar pembelajaran yang berfungsi untuk menghasilkan siswa yang memiliki 
kemampuan berfikir, kemampuan penalaran matematis, memiliki pengetahuan serta keterampilan dasar yang bermanfaat. Satu diantara pembelajaran tersebut yaitu standar proses yang meliputi: pemecahan masalah, penalaran, komunikasi, penelusuran pola atau hubungan, dan representasi. Pemecahan masalah merupakan landasan matematika di sekolah karena menurut Al-Tabany (2014), pemecahan masalah didefinisikan sebagai proses atau upaya untuk mendapatkan suatu penyelesaian tugas atau situasi yang benar-benar nyata sebagai masalah dengan menggunakan aturan-aturan yang sudah diketahui. Pembelajaran berbasis masalah yang terdapat dalam kehidupan sehari-hari juga dapat mengasah keterampilan berpikir tingkat tinggi siswa karena siswa dilatih menganalisis permasalahan tersebut (Sumarli, 2018). Jadi, pembelajaran berdasarkan masalah lebih memfokuskan pada masalah kehidupan nyata yang bermakna bagi siswa.

Kemampuan pemecahan masalah juga merupakan salah satu kemampuan yang dituntut dalam pembelajaran matematika di sekolah. Salah satu tujuan dari pembelajaran matematika adalah agar siswa memiliki kemampuan pemecahan masalah yang meliputi indikator kemampuan memahami masalah, indikator merancang model matematika, indikator menyelesaikan model dan indikator menafsirkan solusi yang diperoleh. Tahapan pemecahan masalah merupakan suatu proses yang kompleks karena di dalam menyelesaikan masalah menuntut siswa mengkoordinasikan antara pengalaman, pengetahuan, dan pemahaman mereka dalam menyelesaikan suatu permasalahan yang dimulai dari mengenal masalah tersebut sampai pada membuktikan kebenaran dari solusi yang dihasilkan (Mariyam, Prihatiningtyas, \& Wahyuni, 2018).

Berdasarkan pernyataan Husna (2018) saat siswa dihadapakan dengan soal yang membutuhkan analisis, seperti soal cerita, siswa tidak terbiasa menuliskan apa yang diketahui dan apa yang ditanyakan dari soal sebelum menyelesaikannya, sehingga siswa sering salah dalam menafsirkan maksud dari soal tersebut. Sebagian besar siswa merasa kesulitan dalam mengubah suatu permasalahan konstektual ke dalam kalimat matematika, sehingga dapat dikatakan bahwa kemampuan siswa dalam menyampaikan ide atau gagasan matematika secara tertulis dari permasalahan konstektual (soal cerita) masih rendah. Selain itu, Kemendikbud (2012) mengungkapkan rendahnya kemampuan pemecahan masalah siswa dibuktikan oleh hasil tes yang dilakukan oleh studi internasional, yaitu Trends in International Mathematics and Science Study (TIMSS) tahun 2011, siswa Indonesia berada pada posisi 41 dari 45 negara dengan perolehan nilai 386. Hasil TIMSS yang dicapai oleh Indonesia yang rendah ini dapat disebabkan oleh beberapa faktor. Salah satu faktor penyebabnya antara lain karena peserta didik di Indonesia kurang terlatih dalam menyelesaikan soalsoal kontekstual, menuntut penalaran, argumentasi dan kreativitas dalam meyelesaikannya. Dimana soal-soal tersebut merupakan karakteristik soal-soal TIMSS.

Menurut Oktavien (2012), untuk dapat mencapai standar-standar pembelajaran, seorang guru hendaknya dapat menciptakan suasana belajar yang memungkinkan bagi siswa untuk secara aktif belajar dengan mengkonstruksi, menemukan, dan mengembangkan pengetahuannya. Karena mengajar matematika tidak sekadar menyusun urutan informasi, tetapi perlu meninjau relevansinya bagi kegunaan dan kepentingan siswa dalam kehidupannya. Dengan ini diharapkan siswa mampu menyelesaikan masalah, menemukan, dan mengkomunikasikan ide-ide khususnya yang berkaitan dengan matematika sehingga memiliki kemampuan pemahaman dan pemecahan masalah yang tentunya diharapkan dapat mencapai hasil yang memuaskan serta mampu menghadapi masalah di dalam kehidupan sehari-hari.

Pada jenjang pendidikan SMP kelas VIII salah satu materi yang dianggap sulit oleh sebagian besar siswa ialah yang mencakup pemahaman tentang gambar, simbol, grafik, tabel, diagram, dan pemecahan masalah. Salah satunya dalam memahami soal pada materi pythagoras. Pythagoras digunakan untuk menentukan jenis segitiga siku-siku yang jika diketahui panjang sisi-sisinya. Salah satu pokok bahasan dalam pythagoras melibatkan bilangan kuadrat dan akar kuadrat dalam sebuah segitiga yang dipelajari untuk memecahkan masalah yang berkaitan dengan segitiga siku-siku. 
Untuk menguji kemampuan pemecahan masalah siswa peneliti melakukan prariset di SMP Negeri 12 Singkawang dengan soal yang berkaitan dengan indikator pemecahan masalah matematis, yaitu (1) memahami masalah, (2) rencana penyelesaian masalah, (3) melaksanakan rencana, dan (4) melakukan pengecekan kembali. Hasil prariset menyatakan bahwa pemecahan masalah matematis siswa masih tergolong rendah. Siswa belum mampu memahami masalah dengan baik. Siswa tidak dapat menuliskan apa yang ditanyakan dari soal. Padahal menuliskan apa yang ditanyakan merupakan bagian dari memahami masalah dalam kemampuan pemecahan masalah. Selain itu, siswa belum bisa menggunakan strategi dalam menyelesaikan masalah. Siswa justru asal-asalan dalam menjawab soal tersebut. Seharusnya siswa terlebih dulu menuliskan rumus yang berkaitan dengan soal untuk menyelesaikan masalah, akibatnya siswa mengalami kesalahan dalam melaksanakan perhitungan yang berkaitan. Sebagian siswa juga lebih memilih melihat jawaban dari teman sekitarnya. Padahal jawaban yang dihasilkan oleh siswa tersebut belum tentu benar. Dari hasil tersebut dapat disimpulkan bahwa kemampuan pemecahan masalah siswa di SMP Negeri 12 Singkawang tergolong rendah.

Selain itu, berdasarkan wawancara yang dilakukan kepada salah satu guru mata pelajaran di SMP Negeri 12 Singkawang tersebut serta pengalaman peneliti di lapangan menunjukkan bahwa kemampuan pemecahan masalah matematika siswa secara umum masih belum optimal. Siswa mulai kebingungan jika dihadapkan dengan masalah non rutin. Jika dihadapkan dengan soal matematika misalnya yang berkaitan pada materi pythagoras, beberapa diantaranya ada siswa yang dapat mengerjakan soal-soal matematika berdasarkan apa yang dicontohkan guru, namun jika diberikan soal yang berbeda maka siswa akan mengalami kesulitan dalam menyelesaikannya. Hal ini menunjukkan adanya faktor-faktor kognitif yang berbeda diantara siswa tersebut yang mempengaruhi kemampuan pemecahan masalah. Dampak dari kondisi ini mengakibatkan banyak siswa yang tidak dapat memahami konsep-konsep matematika dengan baik sehingga cenderung memperoleh hasil belajar matematika yang kurang memuaskan.

Ngilawajan (2013) mengungkapkan bahwa dalam memecahkan masalah matematika, setiap orang memiliki cara dan gaya berpikir yang berbeda-beda karena tidak semua orang memiliki kemampuan berpikir yang sama. Perbedaan individu dapat diungkapkan oleh tipe-tipe kognitif yang dikenal dengan istilah gaya kognitif. Gaya kognitif dapat didefinisikan sebagai variasi cara seseorang menerima, mengingat, dan berpikir atau sebagai cara-cara khusus dalam menerima, menyimpan, membentuk, dan memanfaatkan informasi. Menurut Vendiagrys (2015), gaya kognitif meliputi sikap yang stabil, pilihan, atau strategi kebiasaan yang membedakan gaya individu dalam merasakan, mengingat, berpikir, dan memecahkan masalah. Gaya kognitif merupakan cara seseorang memproses, menyimpan maupun menggunakan informasi untuk menanggapi suatu tugas atau berbagai jenis lingkungannya. Selain itu, Ulya (2015) menyatakan bahwa kemampuan pemecahan masalah dalam matematika siswa dapat dipengaruhi oleh beberapa faktor. Faktor tersebut muncul karena setiap individu memiliki perbedaan. Dimensi-dimensi perbedaan individu antara lain adalah inteligensi, kemampuan berpikir logis, kreativitas, gaya kognitif, kepribadian, nilai, sikap, dan minat. Uraian di atas dapat disimpulkan bahwa seseorang memiliki kemampuan yang berbeda dalam memecahkan masalah. Perbedaan tersebut dipengaruhi oleh berbagai faktor baik secara kelompok maupun secara individu.

Haloho (2016) mengungkapkan bahwa gaya kognitif dikategorikan menjadi gaya kognitif Field Independent (FI) dan Field Dependent (FD). Menurut Arifin (2015), siswa dengan gaya kognitif FI cenderung memilih belajar individual, menanggapi dengan baik, dan bebas (tidak bergantung pada orang lain), sedangkan siswa yang memiliki gaya kognitif FD cenderung memilih belajar dalam kelompok dan sesering mungkin berinteraksi dengan siswa lain atau guru, memerlukan ganjaran atau penguatan yang bersifat ekstrinsik. Purnomo (2015) mengklasifikasikan gaya kognitif antara lain: (1) perbedaan gaya kognitif secara psikologis, meliputi: gaya kognitif field dependent dan gaya kognitif field independent; (2) perbedaan gaya kognitif secara konseptual tempo, meliputi: gaya kognitif impulsif dan gaya kognitif refleksif; (3) perbedaan gaya kognitif berdasarkan cara berpikir, meliputi: gaya kognitif intuitif-induktif dan logik-deduktif. Dalam penelitian ini, peneliti memilih fokus pada tipe gaya kognitif field dependent dan gaya kognitif field independent. 
Berdasarkan penelitian yang dilakukan oleh Santia (2015) menunjukkan bahwa subjek dengan gaya kognitif field dependent sangat bergantung pada gambar dalam pemecahan masalah. Sedangkan, subjek dengan gaya kognitif field independent tidak selalu menggunakan gambar dan memiliki ragam representasi simbol yang cukup baik. Penelitian yang dilakukan oleh Akramunnisa (2015), subjek yang bergaya kognitif FI kemampuannya dalam menyelesaikan masalah terurut, jelas, dan analitis. Dalam menyelesaikan masalah mampu menganalisis masalah dengan baik dengan kemampuan awal matematika yang tinggi. Selain itu, penelitian yang dilakukan oleh Khakim (2016), siswa dengan gaya kognitif FD cenderung memiliki kemampuan pemecahan masalah yang tinggi, yaitu siswa FD kelompok atas dan siswa FD kelompok sedang. Siswa FD kelompok bawah cenderung memiliki kemampuan pemecahan masalah yang rendah. Siswa dengan gaya kognitif FI cenderung memiliki kemampuan pemecahan masalah yang rendah, yaitu siswa FI kelompok sedang dan siswa FI kelompok bawah. Siswa FI kelompok atas cenderung memiliki kemampuan pemecahan masalah yang tinggi. Uraian di atas menunjukkan adanya keterkaitan antara masing-masing tipe gaya kognitif terhadap kemampuan pemecahan masalah siswa sehingga siswa dengan tipe gaya kognitif yang berbeda akan memiliki kemampuan pemecahan masalah yang berbeda pula.

Keberhasilan pembelajaran dipengaruhi oleh banyak faktor, faktor-faktor yang mempengaruhi proses dan hasil belajar adalah faktor internal yang berasal dari dalam diri siswa dan faktor eksternal yang berasal dari luar siswa. Faktor dari dalam individu, meliputi faktor fisik dan psikis, diantaranya adalah minat siswa. Menurut Kristiana (2012), minat adalah kecenderungan seseorang terhadap objek atau suatu kegiatan yang digemari yang disertai dengan perasaan senang, adanya perhatian dan keaktifan berbuat. Minat besar pengaruhnya terhadap hasil belajar siswa, bila bahan pelajaran yang dipelajari tidak sesuai dengan minat siswa, maka siswa tidak akan belajar dengan sebaik-baiknya karena tidak ada daya tarik baginya. Siswa yang tidak berminat terhadap suatu pelajaran tidak mempunyai perhatian terhadap apa yang diajarkan guru, siswa menjadi acuh, tidak mendengarkan penjelasan guru, bahkan ribut sendiri.

Arunti (2013) menyatakan bahwa dengan mengetahui faktor rendahnya prestasi belajar masing-masing siswa akan mempermudah mengambil tindakan selanjutnya untuk mengatasi masalah yang dialami siswa. Dalam hal ini peran guru sangat penting dalam membangkitkan minat belajar siswa. Cara menyajikan bahan pelajaran yang menarik akan membuat siswa tertarik untuk belajar, sedangkan metode mengajar yang kurang baik akan mempengaruhi belajar siswa yang kurang baik pula. Apabila guru mempunyai semangat untuk memperhatikan dan mengenang kegiatan mengajar akan sangat mempengaruhi minat siswa terhadap materi yang diajarkan. Seorang guru tidak dapat membangkitkan minat siswa, jika guru tersebut tidak memiliki minat dalam memberikan materi pelajaran matematika (Siagian, 2015).

Mengacu pada perumusan masalah yang telah dikemukakan pada uraian sebelumnya, maka tujuan penelitian ini adalah (1) Untuk mendeskripsikan kemampuan pemecahan masalah siswa dengan gaya kognitif Field Dependent pada materi pythagoras di kelas VIII, (2) Untuk mendeskripsikan kemampuan pemecahan masalah siswa dengan gaya kognitif Field Independent pada materi pythagoras di kelas VIII, (3) Untuk mengetahui faktor yang mempengaruhi kemampuan belajar siswa pada materi pythagoras di kelas VIII.

\section{METODE PENELITIAN}

Metode penelitian kualitatif adalah metode penelitian yang berlandaskan pada filsafat postpositivisme, digunakan untuk meneliti pada kondisi obyek yang alamiah, (sebagai lawannya adalah eksperimen) dimana peneliti adalah sebagai instrumen kunci, teknik pengumpulan data dilakukan secara triangulasi (gabungan), analisis data bersifat induktif/ kualitatif, dan hasil penelitian kualitatif lebih menekankan makna daripada generalisasi (Sugiyono, 2014). Jenis penelitian yang digunakan dalam penelitian ini adalah metode penelitian dengan pendekatan kualitatif. Subjek yang diteliti pada penelitian ini adalah siswa kelas VIII A di SMP Negeri 12 Singkawang yang berjumlah 21 siswa. Objek dalam penelitian 
ini adalah kemampuan pemecahan masalah matematis yang memiliki gaya kognitif field independent (FI) dan field dependent (FD).

Teknik pengumpulan data yang akan digunakan dalam penelitian ini adalah teknik pengukuran, wawancara, dan dokumentasi. Instrumen pengumpulan data yang akan digunakan dalam penelitian ini adalah tes untuk mengukur gaya kognitif siswa berupa The Group Embedded Figure Test (GEFT) yang dikembangkan oleh Oltman, Raskin, \& Witkin (Fitriana, 2014) yang digunakan untuk mengetahui gaya kognitif siswa berdasarkan perbedaan psikologinya yaitu gaya kognitif field dependent dan gaya kognitif field independent. Pengujian keabsahan data menggunakan uji kredibilitas yang dilakukan dengan cara triangulasi, meningkatkan ketekunan dan menggunakan bahan referensi. Teknik analisis data dalam penelitian ini mengacu pada pendapat Miles and Huberman (Sugiyono, 2015) yang mengemukakan bahwa aktivitas dalam analisis data kualitatif dilakukan secara interaktif dan berlangsung secara terus-menerus sampai tuntas, sehingga datanya sudah jenuh. Aktivitas dalam analisis data berupa data reduction, data display, dan conclusion drawing/verification.

\section{HASIL DAN PEMBAHASAN}

\section{Gaya Kognitif Siswa}

Dalam penelitian ini, subjek penelitian ditentukan berdasarkan gaya kognitif siswa melalui Group Embedded Figure Test (GEFT). Setelah peneliti mengumpulkan, mengoreksi, menilai, dan merekap data hasil GEFT, peneliti mengelompokkan siswa menjadi dua kelompok yaitu siswa dengan gaya kognitif field dependent (FD) dan siswa dengan gaya kognitif field independent (FI). Berdasarkan hasil GEFT yang diperoleh siswa kelas VIII A SMP Negeri 12 Singkawang terdapat 21 orang siswa dengan gaya kognitif field dependent (FD) dengan jumlah skor total tertinggi 11 dan jumlah skor total terendah nol. Adapun data yang diperoleh dari hasil analisis pengisian instrumen GEFT disajikan dalam Tabel 1.

Tabel 1. Gaya Kognitif Siswa Kelas VIII A SMP Negeri 12 Singkawang

\begin{tabular}{cc}
\hline Gaya Kognitif & Jumlah Siswa \\
\hline Field Dependent & 21 \\
Field Independent & 0 \\
\hline
\end{tabular}

Berdasarkan data dalam Tabel 1 terdapat 7 siswa kelompok tinggi bergaya kognitif FD, 8 siswa kelompok sedang bergaya kognitif FD, dan 6 siswa kelompok rendah bergaya kognitif FD. Setelah diperoleh data tersebut, peneliti memilih subjek penelitian yaitu 2 siswa bergaya kognitif FD kelompok tinggi, 2 siswa bergaya kognitif FD kelompok sedang, dan 2 siswa bergaya kognitif FD kelompok rendah.

\section{Kemampuan Pemecahan Masalah Siswa Field Dependent Kelas VIII A}

Setelah pelaksanaan tes kemampuan pemecahan masalah dilakukan, selanjutnya pekerjaan siswa diperiksa dan dilanjutkan dengan penskoran. Setelah melakukan penskoran langkah selanjutnya yang dilakukan adalah menganalisis hasil yang diperoleh, yaitu dengan menghitung persentase jawaban benar masing-masing indikator pada soal yang diberikan kepada siswa.

Berdasarkan pernyataan di atas, berikut grafik hasil kemampuan pemecahan masalah siswa berdasarkan indikator kemampuan pemecahan masalah dalam bentuk diagram batang seperti pada Gambar 1. Pada Gambar 1 dapat diketahui bahwa kemampuan pemecahan masalah siswa filed dependent kelompok tinggi pada indikator melaksanakan rencana lebih baik dibandingkan indikator kemampuan pemecahan masalah lainnya. Sedangkan pada kemampuan pemecahan masalah siswa filed dependent kelompok sedang dan kelompok rendah pada indikator memahami masalah lebih baik dibandingkan indikator kemampuan pemecahan masalah lainnya. 


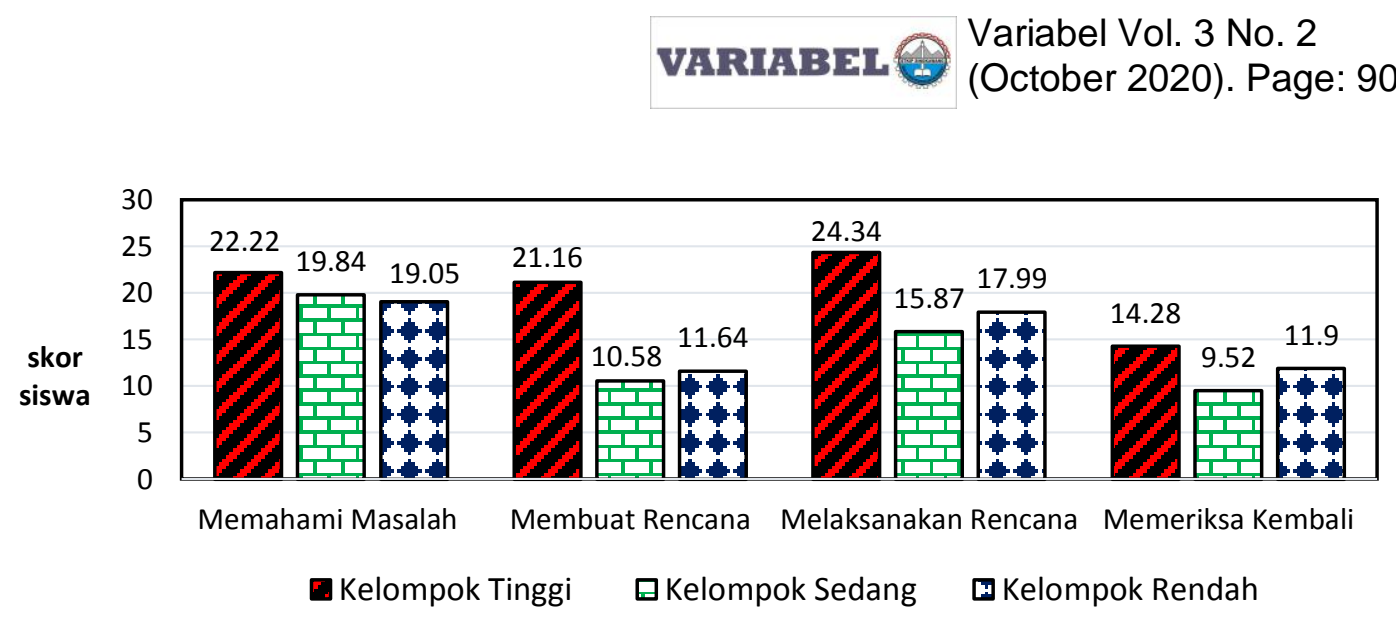

\section{Gambar 1. Diagram Hasil Kemampuan Pemecahan Masalah Siswa Field Dependent Berdasarkan Masing-Masing Indikator}

Untuk mengetahui kemampuan pemecahan masalah siswa dengan gaya kognitif FD siswa dikelompokkan ke dalam tiga bagian yaitu kelompok tinggi, sedang, dan rendah. Dengan adanya pengelompokan tersebut, maka jawaban siswa ditentukan untuk dianalisis dan sekaligus siswa yang akan diwawancarai adalah siswa-siswa dengan nomor kode S-21,S-04, S-20,S-16, S-14, dan S-07. Jawaban pada tes dan hasil wawancara dari enam siswa tersebut dianalisis untuk menentukan kemampuan pemecahan masalah siswa pada indikator memahami masalah, membuat rencana penyelesaian, melaksanakan rencana, dan memeriksa kembali beserta faktor yang mempengaruhinya. Hasil dari analisis data tes dan analisis data wawancara dibandingkan untuk mendapatkan kesimpulan berupa data yang valid mengenai pemecahan masalah siswa dan faktor yang mempengaruhinya. Setelah melakukan analisis kemampuan pemecahan masalah untuk tiap gaya kognitif siswa, maka diperoleh ringkasan mengenai kemampuan pemecahan masalah untuk tiap gaya kognitif. Sementara itu, untuk kemampuan pemecahan masalah subjek dengan gaya kognitif FI tidak dapat dilakukan penjelasan mengenai data yang diperoleh dikarenakan tidak adanya siswa yang berkemampuan FI di kelas tersebut.

\section{Kemampuan Pemecahan Masalah dengan Gaya Kognitif FD Kelompok Tinggi}

a. Indikator Memahami Masalah

$$
\begin{aligned}
& \text { Diceet } \\
& \text { 'A Jaraue kaki fangga }=12 \mathrm{~cm} \\
& \text { Panjang tangga disandamcern }=15 \mathrm{~cm} \\
& \frac{\text { Dita }}{\text { tinggi tembok terselat? }}
\end{aligned}
$$

Gambar 2. Cuplikan Jawaban Subjek S-21 pada Indikator Memahami Masalah

Pada tahap indikator memahami masalah subjek FD S-21 dan S-04 mampu menuliskan apa yang diketahui dan ditanyakan dari soal dengan baik. Subjek mampu menyatakan menggunakan kalimat sendiri meskipun tidak jauh berbeda dengan kalimat yang terdapat dalam soal. Selain itu, pada saat wawancara subjek FD juga mampu menyebutkan apa yang diketahui dan ditanyakan dengan baik. Hal ini senada dengan Amstrong, Cool, and Eugene (Vendiagrys, 2015) bahwa individu FD mengadopsi suatu orientasi global untuk memahami dan memproses informasi.

\section{b. Indikator Membuat Rencana Penyelesaian}

Pada tahap indikator membuat rencana penyelesaian, subjek FD kelompok tinggi cenderung mampu sampai tidak mampu membuat rencana penyelesaian dengan baik. Sebagian subjek FD kelompok tinggi sudah mampu menuliskan langkah-langkah untuk menyelesaikan masalah, namun masih ada yang tidak mampu dalam menyelesaikan masalah. Subjek FD kelompok tinggi menuliskan rencana yang dibuat dengan tidak lepas dari latar belakang pada soal. Seperti pada soal nomor 2, diketahui bahwa kain yang digunting tersebut berbentuk belah ketupat. Dalam hal tersebut terdapat subjek FD 
yang menuliskan salah satu rencana yang digunakan untuk mencari diagonal belah ketupat dan kemudian menarik salah satu sisi pembentuk segitiga siku-siku. Subjek FD melihat masalah tersebut secara global dan menuliskan rencana yang digunakan tidak lepas dari latar belakang belah ketupat yang diketahui pada soal tersebut. Hal ini senada dengan Istiqomah (2014) bahwa seseorang dikatakan mempunyai gaya kognitif FD jika seseorang menerima sesuatu lebih secara global. Hal ini juga sesuai seperti yang dikemukakan Witkin dan Goodenough (Ngilawajan, 2013) bahwa individu dengan gaya kognitif field dependent (FD) adalah individu yang kurang atau tidak bisa memisahkan sesuatu bagian dari suatu kesatuan dan cenderung segera menerima bagian atau konteks yang dominan.

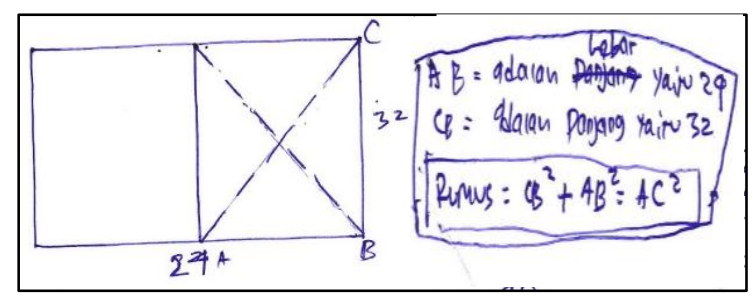

Gambar 3. Cuplikan Jawaban Subjek S-21 pada Indikator Membuat Rencana

c. Indikator Melaksanakan Rencana

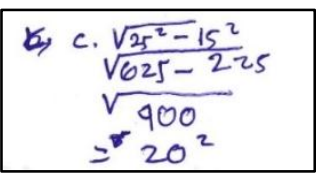

Gambar 4. Cuplikan Jawaban Subjek S-21 pada Indikator Melaksanakan Rencana

Pada tahap indikator melaksanakan rencana, subjek FD kelompok tinggi cenderung mampu sampai tidak mampu melaksanakan rencana penyelesaian dengan baik. Sebagian subjek FD mampu menuliskan langkah-langkah dalam perhitungan untuk menyelesaikan soal dengan benar, namun sebagian yang lain tidak mampu. Dari hasil yang diperoleh, terdapat subjek FD yang tidak dapat memperoleh jawaban dengan benar karena rencana pemecahan masalah dan strategi yang digunakan salah. Terdapat juga subjek FD yang keliru menerapkan rumus ketika menemukan masaalah yang dianggap sulit. Hal ini senada dengan Vendiagrys (2015) bahwa subjek FD menggunakan langkahlangkah pemecahan masalah tetapi sering tidak dapat memperoleh ketepatan jawaban yang benar.

d. Indikator Memeriksa Kembali

$$
\begin{aligned}
& \text { D) Banar, bahwa BC adalah } 10 \mathrm{~m} \\
& \text { Jadi, pansang sisi } B C \text { adalah } 10 \mathrm{~m} \text {. }
\end{aligned}
$$

Gambar 5. Cuplikan Jawaban Subjek S-04 pada Indikator Memeriksa Kembali

Pada tahap indikator memeriksa kembali, subjek FD kelompok tinggi cenderung mampu sampai tidak mampu dalam melakukan pengecekan kembali terhadap jawaban yang diperoleh. Subjek FD mampu melakukan pengecekan terhadap jawaban yang diperoleh. Namun terdapat subjek FD yang melakukan kesalahan dalam melakukan pengecekan. Dalam hal ini, seperti yang diungkap Khoiriyah (2013) bahwa subjek FD cenderung kesulitan dalam memproses informasi yang diberikan, kecuali informasi tersebut telah diubah atau dimanipulasi ke dalam bentuk yang biasa mereka kenal. Seperti pada soal nomor 3, terdapat subjek FD yang tidak mampu menemukan alternatif lain untuk menyelesaikan masalah pada indikator memeriksa kembali. Sehingga subjek FD hanya menuliskan kesimpulan pada tahap memeriksa kembali tanpa melakukan perhitungan ulang untuk mengetahui kebenaran jawaban yang diperoleh. Hal ini sejalan dengan Goodenough (Karacam \& Digilibaran, 2015) bahwa siswa FD cenderung mengenali konsep yang diberikan pada materi dan petunjuk secara eksplisit. 


\section{Kemampuan Pemecahan Masalah dengan Gaya Kognitif FD Kelompok Sedang}

a. Indikator Memahami Masalah

$$
\begin{aligned}
& \text { (.A.) arak kaki tan 99a }=12 \text {, y9disandarka \&e Tembok adalab } 15 \mathrm{~cm} \\
& \text { Berapakah tin99i tembot }
\end{aligned}
$$

Gambar 6. Cuplikan Jawaban Subjek S-20 pada Indikator Memahami Masalah

Pada tahap indikator memahami masalah, subjek FD kelompok sedang cenderung tidak mampu sampai mampu dalam memahami masalah yang diberikan. Sebagian subjek FD sudah mampu menuliskan apa yang diketahui dan ditanyakan dari soal dengan benar, namun sebagian yang lain tidak mampu menuliskan apa yang diketahui dan ditanyakan pada soal dengan benar. Subjek FD kelompok sedang cenderung menyatakan hal yang sama terhadap kalimat apa yang ada di dalam soal. Seperti pada soal nomor 2, terdapat subjek FD yang menuliskan ulang kalimat yang terdapat dalam soal untuk menjawab apa yang diketahui. Hal ini sejalan dengan Vendiagrys (2015) yang menyatakan bahwa subjek FD cenderung menerima informasi apa adanya tanpa menyesuaikan dengan bahasa matematika, subjek masih menuliskan apa yang diketahui dan ditanyakan dalam bentuk kalimat verbal seperti dalam soal. Hal ini juga dikemukakan oleh Riding \& Cheema (Ngilawajan, 2013) bahwa individu yang memiliki gaya kognitif FD cenderung sulit untuk memisahkan suatu informasi yang diterima dari hal-hal konteks disekitarnya dan tidak selektif dalam menyerap informasi.

b. Indikator Membuat Rencana Penyelesaian

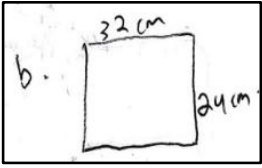

Gambar 7. Cuplikan Jawaban Subjek S-20 pada Indikator Membuat Rencana

Pada tahap indikator membuat rencana penyelesaian, subjek FD kelompok sedang cenderung tidak mampu membuat rencana penyelesaian masalah dengan baik. Subjek FD kelompok sedang tidak mampu menuliskan langkah-langkah untuk menyelesaikan permasalahan. Subjek FD tidak dapat memperoleh jawaban yang benar karena rencana dan strategi yang digunakan tidak tepat. Dari hasil wawancara yang diperoleh subjek FD kelompok sedang tidak mampu menyebutkan rumus atau tahaptahap apa saja yang dilakukan untuk menjawab soal. Adapun subjek FD cenderung menyontek dan menunggu jawaban dari teman disekitarnya. Secara umum subjek FD tidak mampu membuat rencana penyelesaian masalah. Hal ini juga senada dengan Istiqomah (2014) yang menyatakan bahwa seseorang dikatakan mempunyai gaya kognitif FD jika seseorang yang menerima sesuatu lebih secara global dan mengalami kesulitan untuk memisahkan diri dari keadaan sekitarnya atau lebih dipengaruhi oleh lingkungan.

c. Indikator Melaksanakan Rencana

$$
\begin{aligned}
\sqrt{5^{2}-12} & =\sqrt{225-149} \\
& \sqrt{225-144} \\
& =81 \\
& =9
\end{aligned}
$$

Gambar 8. Cuplikan Jawaban Subjek S-20 pada Indikator Melaksanakan Rencana

Pada tahap indikator melaksanakan rencana, subjek FD kelompok sedang cenderung tidak mampu melaksanakan rencana penyelesaian dengan baik. Subjek FD kelompok sedang cenderung tidak mampu menuliskan langkah-langkah dalam melakukan perhitungan. Dari wawancara yang diperoleh subjek FD kelompok sedang cenderung tidak memahami rumus yang digunakan untuk menyelesaikan 
masalah. Terdapat subjek FD yang mampu menuliskan langkah-langkah dalam perhitungan, namun pada saat wawancara tidak dapat menjelaskan proses pada langkah-langkah tersebut. Secara umum subjek FD kelompok sedang tidak mampu melaksanakan rencana penyelesaian masalah. Hal ini sejalan dengan Prabawa (2017) bahwa subjek FD mampu menerjemahkan masalah yang diberikan dalam bentuk kalimat matematika dan menuliskan rumus untuk menyelesaikan permasalahan, namun kurang mampu menghitung dengan manipulasi aljabar yang tepat untuk menentukan penyelesaian masalah.

\section{d. Indikator Memeriksa Kembali}

Pada tahap indikator memeriksa kembali, subjek FD kelompok sedang cenderung tidak mampu melakukan pengecekan kembali dengan baik. Subjek FD kelompok sedang tidak mampu menuliskan kesimpulan dan tidak melakukan pemeriksaan kembali pada jawaban yang diperoleh. Menurut Cao (2006) berpendapat bahwa individu FD dipandang sebagai pelajar pasif dalam memahami informasi pembelajaran. Mereka lebih dirugikan dalam situasi yang tidak terstruktur, dan mereka memerlukan instruksi yang lebih eksplisit dan deskripsi yang lebih rinci. Hal ini juga senada dengan pendapat Haloho (2016) bahwa individu FD mengalami kesukaran untuk membuat objek yang terstruktur menjadi tidak terstruktur, namun tidak kesulitan dalam memecahkan masalah sosial.

\section{Kemampuan Pemecahan Masalah dengan Gaya Kognitif FD Kelompok Rendah}

a. Indikator Memahami Masalah

$$
\begin{aligned}
& \text { A Jatak kaki tang9a: } 12 \mathrm{~cm} \\
& \text { Panjang tangga di saderhanakan = } 15 \text { mem } \\
& \text { fingg: Dita tambok terr bot? }
\end{aligned}
$$

Gambar 9. Cuplikan Jawaban Subjek S-14 pada Indikator Memahami Masalah

Pada tahap indikator memahami masalah, subjek FD kelompok rendah cenderung mampu sampai tidak mampu dalam memahami masalah yang diberikan. Sebagian subjek FD kelompok rendah mampu menuliskan apa yang diketahui dan ditanyakan pada soal dengan benar, namun sebagian yang lain belum mampu menuliskan apa yang diketahui dan ditanyakan pada soal dengan benar. Hal tersebut ditunjukkan dengan hasil tes dan wawancara subjek FD kelompok rendah pada soal nomor 2 . Subjek FD mampu menuliskan apa yang diketahui, namun tidak mampu menuliskan apa yang ditanyakan dengan baik. Hal ini sesuai dengan pendapat Arifin (2015) yang mengatakan bahwa individu dengan gaya kognitif FD kurang dapat menginterpretasikan soal dalam pemahamannya melalui tulisan.

b. Indikator Membuat Rencana Penyelesaian

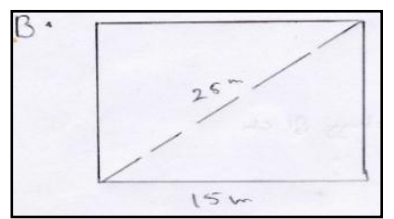

Gambar 10. Cuplikan Jawaban Subjek S-07 pada Indikator Membuat Rencana

Pada tahap indikator membuat rencana penyelesaian, subjek FD kelompok rendah cenderung tidak mampu membuat rencana penyelesaian masalah dengan baik. Subjek FD kelompok rendah mampu membuat langkah-langkah dalam rencana penyelesaian namun tidak lengkap. Subjek FD hanya membuat gambar yang berkaitan pada soal namun tidak membuat rencana berupa rumus atau langkahlangkah yang akan digunakan untuk menyelesaikan masalah yang diberikan. Dari hasil wawancara yang diperoleh subjek FD kelompok rendah cenderung lebih mengharapkan bantuan teman daripada bertanya kepada guru yang bersangkutan. Hal ini sesuai dengan pendapat Arifin (2015) bahwa 
individu dengan gaya kognitif FD dapat memperoleh informasi tetapi kurang dapat mengorganisasi informasi tersebut ke dalam bentuk tulisan.

c. Indikator Melaksanakan Rencana

$$
\begin{aligned}
& C \sqrt{15^{2}-12^{2}} \\
& \sqrt{225-144} \\
& =81
\end{aligned}
$$

Gambar 11. Cuplikan Jawaban Subjek S-14 pada Indikator Melaksanakan Rencana

Pada tahap indikator melaksanakan rencana, subjek FD kelompok rendah cenderung kurang mampu menerapkan langkah-langkah penyelesaian dengan baik. Subjek FD kelompok rendah cenderung mampu menuliskan langkah-langkah dalam melakukan perhitungan, namun tidak dapat memperoleh jawaban yang benar. Hal ini disebabkan karena strategi yang digunakan tidak tepat. Hal ini senada dengan Vendiagrys (2015) bahwa subjek FD menggunakan langkah-langkah pemecahan masalah tetapi sering tidak dapat memperoleh ketepatan jawaban yang benar.

\section{d. Indikator Memeriksa Kembali}

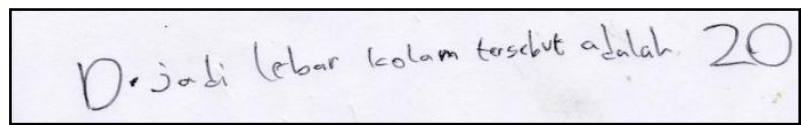

Gambar 12. Cuplikan Jawaban Subjek S-07 pada Indikator Memeriksa Kembali

Pada tahap indikator memeriksa kembali, subjek FD kelompok rendah cenderung mampu sampai tidak mampu dalam melakukan pengecekan kembali terhadap jawaban yang diperoleh. Subjek FD kelompok rendah cenderung menuliskan kesimpulan, tetapi tidak melakukan pengecekan terhadap jawaban yang diperoleh. Namun ada juga subjek FD yang melakukan pengecekan ulang terhadap jawaban yang diperoleh pada beberapa nomor. Hal ini dapat ditunjukkan dengan hasil wawancara salah satu subjek FD kelompok rendah S-07 terhadap jawaban yang diperoleh pada nomor satu dan nomor tiga. Subjek S-07 melakukan pengecekan dengan cara melihat kembali langkah-langkah perhitungan yang telah diselesaikan sebelumnya. Hal ini sejalan dengan Ahmadzade \& Shojae (2013) bahwa siswa FD hanya dapat memahami satu aspek dari sebuah konsep dan tidak mampu membedakan secara rinci. Khoiriyah (2013) juga berpendapat bahwa siswa yang memiliki gaya kognitif FD cenderung menerima suatu pola sebagai suatu keseluruhan.

\section{Faktor Yang Mempengaruhi Kemampuan Belajar Siswa}

Faktor internal yang mempengaruhi kemampuan belajar siswa berdasarkan hasil analisis yang diperoleh yaitu: (1) Siswa tidak mampu menemukan konsep-konsep dalam memahami masalah pada soal. (2) Strategi pemecahan masalah yang tidak tepat. Hal ini menyebabkan langkah-langkah atau proses perhitungan yang dilakukan juga tidak tepat. (3) Siswa tidak mampu melakukan proses perhitungan dan menyelesaikan soal yang telah dilaksanakan. (4) Siswa kurang paham terhadap konsep pythagoras sehingga siswa tidak dapat menyusun rencana penyelesaian pada masalah yang diberikan. (5) Siswa malas untuk bertanya saat mengalami kesulitan, sehingga hal itu membuat siswa tidak dapat menjawab pertanyaan yang terdapat pada soal tes. (6) Siswa malas melakukan pengecekan kembali. (7) Siswa kurang teliti dalam menyelesaikan soal tes, sehingga tahapan-tahapan yang dilakukan kurang tepat.

Faktor eksternal yang mempengaruhi kemampuan belajar siswa berdasarkan hasil analisis yang diperoleh yaitu: (1) Alokasi waktu yang diberikan tidak cukup, sehingga beberapa siswa tidak memiliki waktu yang cukup untuk menyelesaikan soal tes. (2) Kondisi kelas yang ribut membuat konsentrasi siswa terganggu. Selain itu, terdapat beberapa siswa yang tidak sungguh-sungguh saat 
mengerjakan soal tes, bermain-main, dan mengobrol saat tes berlangsung, sehingga hasil yang diperoleh kurang maksimal.

Hal ini sesuai dengan pendapat Shadiq (2014) yang menyatakan bahwa faktor penyebab yang mempengaruhi kemampuan belajar siswa dapat berasal dari dalam diri siswa itu sendiri dan dapat juga dari luar. Senada dengan pendapat di atas, Slameto (Awaliyah, 2015) mengungkapkan bahwa faktor internal yang mempengaruhi belajar siswa meliputi jasmani, psikologis, dan kelelahan. Faktor eksternal yang mempengaruhi kemampuan belajar siswa meliputi keluarga, sekolah, dan masyarakat.

\section{KESIMPULAN}

Kemampuan pemecahan masalah siswa dengan gaya kognitif field dependent (FD) kelompok tinggi cenderung memiliki kemampuan pemecahan masalah dengan kategori baik. Siswa mampu menentukan apa yang diketahui dan ditanyakan, mampu menentukan rencana dan rumus yang sesuai untuk menyelesaikan masalah, mampu menerapkan rencana dan rumus yang sudah ditentukan untuk menyelesaikan masalah, namun ada yang tidak mampu, serta mampu menuliskan kesimpulan akhir dan mengecek kembali rencana dan perhitungan yang dilakukan. Kemampuan pemecahan masalah siswa dengan gaya kognitif field dependent (FD) kelompok sedang cenderung memiliki kemampuan pemecahan masalah dengan kategori kurang baik. Siswa mampu menentukan apa yang diketahui dan ditanyakan, sebagian yang lain tidak mampu. Siswa tidak mampu menentukan rencana dan rumus yang sesuai untuk menyelesaikan masalah, tidak mampu menerapkan rencana dan rumus yang sudah ditentukan untuk menyelesaikan masalah, serta tidak mampu menuliskan kesimpulan akhir dan mengecek kembali rencana dan perhitungan yang dilakukan. Kemampuan pemecahan masalah siswa dengan gaya kognitif field dependent (FD) kelompok rendah cenderung memiliki kemampuan pemecahan masalah dengan kategori cukup baik. Siswa mampu menentukan apa yang diketahui dan ditanyakan, namun ada yang tidak mampu. Pada indikator membuat rencana, subjek FD tidak mampu menentukan rencana dan rumus yang sesuai untuk menyelesaikan masalah. Pada indikator melaksanakan rencana, sebagian subjek FD tidak mampu menerapkan rencana dan rumus yang sudah ditentukan untuk menyelesaikan masalah dan sebagian yang lain mampu. Pada indikator memeriksa kembali subjek FD mampu menuliskan kesimpulan, namun ada yang tidak mampu. Berdasarkan analisis kemampuan pemecahan masalah matematis siswa ditinjau dari gaya kognitif field independent (FI) tidak dapat dilakukan kesimpulan dikarenakan tidak adanya siswa dengan gaya kognitif FI di kelas tersebut. Faktor internal yang mempengaruhi kemampuan belajar siswa yaitu, siswa tidak mampu menemukan konsep-konsep dalam memahami masalah, strategi pemecahan masalah yang tidak tepat, tidak mampu melakukan proses perhitungan dan menyelesaikan soal, kurang paham terhadap konsep pythagoras, malas, kurang teliti dalam menyelesaikan soal. Faktor eksternal yang mempengaruhi kemampuan belajar siswa yaitu, alokasi waktu yang diberikan tidak cukup, kondisi kelas yang ribut, tidak sungguh-sungguh saat mengerjakan soal tes, bermain-main, dan mengobrol saat tes berlangsung, sehingga hasil yang diperoleh kurang maksimal.

\section{DAFTAR PUSTAKA}

Ahmadzade, L. \& Shojae, M. (2013). Investigating the Relationship between Cognitive Style (Filed Dependence/Independence) and Academic Achievement in Male and Female Students of Behbahan Islamic Azad University. Journal of Life Science and Biomedicine, 3(3), 245-249.

Akramunnisa. (2015). Analisis Kemampuan Menyelesaikan Masalah Matematika Ditinjau Dari Kemampuan Awal Tinggi Dan Gaya Kognitif Field Independent (FI). Jurnal Pedagogy, 1(2), 46-56.

Al-Tabany, Trianto I.B. (2014). Mendesain Model Pembelajaran Inovatif, Progresif, dan Kontekstual. Jakarta: Kencana.

Arifin, Sadriwanti. (2015). Profil Pemecahan Masalah Matematika Siswa Ditinjau Dari Gaya Kognitif Dan Efikasi Diri Pada Siswa Kelas VIII Unggulan SMPN 1 Watampone. Jurnal Daya Matematis, 3(1), 20-29. 
Arunti, Rindang. (2013). Faktor-Faktor Yang Mempengaruhi Rendahnya Prestasi Belajar Matematika Pada Siswa Kelas V Madrasah Ibtidaiyah Negeri Ponjong Gunungkidul Tahun Ajaran 2012/2013. Skripsi. Yogyakarta: UI Negeri Sunan Kalijaga.

Awaliyah, Ghaida. (2015). Pengaruh Kemampuan Pemecahan Masalah terhadap Hasil Belajar Matematika Siswa Kelas V SD Se-Gugus Ki Hajar Dewantara Kecamatan Tegal Timur Kota Tegal. Skripsi. Semarang: FKIP Universitas Negeri Semarang.

Cao. Y. (2006). Effects of Field Dependent-Independent Cognitive Styles and Cueing Strategies on Students' Recall and Comprehension. Dissertation. Blacksburg VA: Faculty of the Virginia Polytechnic Institute and State University.

Fitriana, Laela. (2014). Analisis Pemahaman Siswa Mengenai Konsep Limit Fungsi Berdasarkan Teori APOS Ditinjau dari Gaya Kognitif (Field Dependent dan Field Independent) di Kelas XI IPA 2 MAN Rejotangan Tahun 2012/2013. Skripsi. Tulungagung: Fakultas Tarbiyah dan Ilmu Keguruan IAIN.

Haloho, Synthia H. (2016). Analisis Kemampuan Pemecahan Masalah Ditinjau Dari Gaya Kognitif Siswa Pada Model Pembelajaran Missouri Mathematics Project. Skripsi. Semarang: FMIPA Unnes.

Husna, Nurul. (2018). Penerapan Model Pembelajaran Problem Solving untuk Meningkatkan Kemampuan Komunikasi Matematis Siswa di SMP. Variabel, 1(1), 36-41.

Istiqomah, Nurul. (2014). Proses Berpikir Siswa Sekolah Menengah Pertama (SMP) dalam Menyelesaikan Soal Cerita Matematika Berdasarkan Gaya Kognitif pada Materi Bangun Ruang Sisi Lengkung. Jurnal Ilmiah Pendidikan Matematika, 3(2), 144-149.

Karacam, S. \& Digilibaran, A. (2015). The effects of field dependent/field independent cognitive styles and motivational styles on students' conceptual understanding about direct current circuits. Asia-Pacific Forum on Science Learning and Teaching, 16(2).

Kemendikbud. (2012). Kemampuan Matematika Siswa SMP Indonesia Menurut Brenchmark Internasional TIMSS 2011. Jakarta: Puspendik.

Khakim, Irwan F. (2016). Analisis Kemampuan Pemecahan Masalah Matematika Ditinjau dari Gaya Kognitif melalui Model SSCS dengan Pendekatan Saintifik pada Siswa Kelas VIII. Skripsi. Semarang: FMIPA Unnes.

Khoiriyah, Nor. (2013). Analisis Tingkat Berpikir Siswa Berdasarkan Teori Van Hiele pada Materi Dimensi Tiga Ditinjau dari Gaya Kognitif Field Dependent dan Field Independent. Skripsi. Surakarta: Fakultas Keguruan dan Ilmu Pendidikan Universitas Sebelas.

Kristiana, Nanik. (2012). Pengaruh Game Online Sara's Cooking Class terhadap Minat dan Motivasi Belajar Siswa Kelas X Jasa Boga pada Mata Pelajaran Pengolahan Makanan Kontinental di SMK N 1 Sewon. Skripsi. Yogyakarta: Fakultas Teknik Universitas Negeri.

Mariyam, Prihatiningtyas, N. C., \& Wahyuni, R. (2018). Pengembangan Kemampuan Pemecahan Masalah Matematis Siswa pada Materi Pertidaksamaan Linier Satu Variabel melalui Model Problem Based Learning Berbantuan Modul. Jurnal Pendidikan Matematika Indonesia, 3(2), 66-73.

Ngilawajan, Darma A. (2013). Proses Berpikir Siswa SMA dalam Memecahkan Masalah Matematika Materi Turunan Ditinjau dari Gaya Kognitif Field Independent dan Field Dependent. Jurnal Pedagogia, 2(1), 71-83.

Oktavien, Yelli. (2012). Meningkatkan Kemampuan Pemahaman dan Pemecahan Masalah Matematis Siswa Sekolah Menengah Atas melalui Pembelajaran Kooperatif Tipe Jigsaw: Studi Eksperimen di SMA Negeri 1 Rengat. Thesis. Universitas Pendidikan Indonesia.

Prabawa, Endra A. (2017). Analisis Kemampuan Pemecahan Masalah Ditinjau dari Gaya Kognitif Siswa pada Model Project Based Learning Bernuansa Etnomatematika. Unnes Journal of Mathematics Education Research, 6(1), 120-129.

Purnomo, D.J. (2015). Tingkat Berpikir Kreatif pada Geometri Siswa Kelas VII Ditinjau dari Gaya Kognitif dalam Setting Problem Based Learning. Unnes Journal of Mathematics Education, 4(2), 109-115.

Rosmaiyadi. (2017). Analisis Kemampuan Berpikir Kritis Matematis Siswa dalam Learning Cycle $7 e$ Berdasarkan Gaya Belajar. Jurnal Pendidikan Matematika, 6(1), 12-19. 
Santia, Ika. (2015). Representasi Siswa SMA dalam Memecahkan Masalah Matematika Berdasarkan Gaya Kognitif. Jurnal Ilmiah Pendidikan Matematika, 3(2), 365-381.

Shadiq, Fadjar. (2014). Pembelajaran Matematika. Yogyakarta: Graha Ilmu.

Siagian, Roida E.F. (2015). Pengaruh Minat dan Kebiasaan Belajar Siswa terrhadap Prestasi Belajar Matematika. Jurnal Formatif, 2(2), 122-131.

Sugiyono. (2014). Cara Mudah Menyusun: Skripsi, Tesis, dan Disertasi. Bandung: CV Alfabeta.

Sugiyono. (2015). Metode Penelitian Pendidikan. Bandung: CV Alfabeta.

Sumarli, S. (2018). Analisis Model Pembelajaran Tipe Think-Pair-Share Berbasis Pemecahan Masalah terhadap Keterampilan Berpikir Tingkat Tinggi Siswa. JIPF (Jurnal Ilmu Pendidikan Fisika), 3(1), 8-13.

Ulya, Himmatul. (2015). Hubungan Gaya Kognitif dengan Kemampuan Pemecahan Masalah Matematika Siswa. Jurnal Konseling Gusjigang, 1(2), 1-12.

Vendiagrys, Lia. (2015). Analisis Kemampuan Pemecahan Masalah Matematika Soal Setipe TIMSS Berdasarkan Gaya Kognitif Siswa pada Pembelajaran Model Problem Based Learning. Unnes Journal of Mathematics Education Research, 4(1), 34-41. 